\title{
PENGARUH KUALITAS PELAYANAN TERHADAP KEPUASAN PELANGGAN PADA PENUMPANG MRT JAKARTA
}

\author{
Erisa Deliyani ${ }^{1}$, Bono Prambudi ${ }^{2}$ \\ ${ }^{1}$ STIE Muhammadiyah Jakarta, erissade196@gmail.com \\ ${ }^{2}$ STIE Muhammadiyah Jakarta, bprambudi@yahoo.com
}

\begin{abstract}
ABSTRAK
Penelitian ini bertujuan menganalisis pengaruh kualitas pelayanan terhadap kepuasan konsumen pada bisnis jasa transportasi MRT Jakarta. Teknik pengambilan sampel yang digunakan adalah purposive sampling sebesar 100 orang yang pernah menggunakan maupun rutin menggunakan MRT sebagai sampel penelitian. Metode analisis data yang digunakan adalah analisis kuantitatif yaitu uji validitas dan reliabilitas, uji asumsi klasik, analisis regresi linear, uji t dan uji $\mathrm{F}$ serta koefisien determinasi. Berdasarkan analisis data, hasil penelitian menunjukkan bahwa indikator-indikator pada penelitian ini bersifat valid dan reliabel. Pada uji asumsi klasik data berdistribusi normal, tidak terjadi heteroskedastisitas dan multikolinieritas. Hasil yang didapat dari pengolahan data SPSS, dapat disimpulkan bahwa Kualitas Pelayanan memiliki pengaruh positif terhadap Kepuasan Pelanggan MRT Jakarta. Hasil ini menunjukkan bukti empiris bahwa semakin baik kualitas pelayanan maka kepuasan pelanggan MRT akan meningkat.
\end{abstract}

\section{Kata kunci: Kualitas Pelayanan, Kepuasan Pelanggan}

\section{ABSTRACT}

This study aims to analyze the effect of service quality on customer satisfaction in the Jakarta MRT transportation service business. The sampling technique used was purposive sampling of 100 people who have used or routinely used the MRT as a research sample. The data analysis method used is a quantitative analysis of the validity and reliability test, the classic assumption test, linear regression analysis, $t$ test and $F$ test and the coefficient of determination. Based on data analysis, the results of the study indicate that the indicators in this study are valid and reliable. In the classical assumption test that the data is normally distributed, there is no heteroscedasticity and multicollinearity. The results obtained from SPSS data processing, it can be concluded that Service Quality has a positive influence on the MRT Jakarta Customer Satisfaction. These results show empirical evidence that the better the quality of service, the MRT customer satisfaction will increase.

\section{Keywords: Service Quality, Customer Satisfaction}

\section{PENDAHULUAN}

Transportasi umum khususnya transportasi darat merupakan salah satu sektor jasa yang memiliki peranan sangat penting bagi perekonomian DKI Jakarta. Namun meskipun begitu, DKI Jakarta sangat lekat dengan kemacetan jalanan yang terjadi pada hampir seluruh penjuru kota. Hal inilah yang masih menjadi pekerjaan rumah bagi pemerintah. Melihat permasalahan kemacetan yang terjadi di DKI Jakarta, dibutuhkan sarana atau alat lain yang dapat mengatasi masalah tersebut. Pelayanan jasa transportasi yang disediakan tentunya harus mengedepankan 
kualitas pelayanan jasa yang efektif dan efisien. Salah satu moda transportasi yang dapat mendukung mobilitas masyarakat dan menjadi alternatif solusi permasalahan saat ini yaitu Mass Rapid Transit atau biasa disingkat MRT. MRT merupakan moda transportasi massal kota yang berbasis rel cepat (fast railway) yang dibangun dengan harapan dapat mengurangi kemacetan di Jakarta. Adanya MRT Jakarta yang cepat dan nyaman diharapkan dapat meningkatkan antusias masyarakat untuk menggunakan transportasi massal.

Transportasi massal merupakan salah satu solusi yang tepat untuk dikembangkan untuk kota-kota yang mengalami kemacetan, khususnya Ibu Kota Jakarta. Hal ini mengingat jumlah kendaraan baru yang masuk ke jalan tidak seimbang dengan pembuatan infrastruktur jalan baru. Pembuatan jalan baru atau pelebaran jalanpun merupakan solusi yang tidak mungkin dilaksanakan karena sudah tidak adanya lahan di Jakarta. Akibat tidak adanya lahan, maka pemerintah provinsi DKI Jakarta pun membuat jalan-jalan layang (flyover). Pembuatan jalan layant bukan merpakan solusi yang tepat karena solusi ini tidak mengurangi keinginan masyarakat untuk membeli kendaraan baru. Untuk menghindari kemacetan dan kepenatan dijalan raya, masyarakat juga cenderung memilih transportasi umum yang nyaman untuk digunakan, misalnya saja KRL. Meskipun kondisi fisik dan kenyamanan KRL cenderung masih belum memuaskan, namun pada kenyataannya masyarakat tetap lebih memilih menggunakan KRL karena dinilai lebih efisien. Maksimalisasi penggunaan transportasi umum diperlukan dalam upaya mengurangi jumlah kendaraan dijalan raya yang berdampak pada berkurangnya kemacetan dijalan. Namun, pada kenyataannya, kondisi transportasi umum yang ada di Jakarta tidak sesuai dengan yang diharapkan oleh masyarakat. Kurangnya kenyamanan karena operator transportasi yang tidak profesional, indisipliner, dalam mengoperasikan moda transportasi dan lebih mementingkan mendapatkan penumpang sebantak-banyaknya dibanding dengan memikirkan keamanan dan kenyamanan penumpang. Berbagai fenomena yang ada dilapangan mengenai transportasi umum banyak dilihat serta dirasakan. Mulai dari supir yang ugal-ugalan, fasilitas yang tidak berfungsi secara optimal, sudah menjadi pemandangan sehari-hari pada moda transportasi kita.

Pengguna kendaraan umum di Jakarta, memang sering kali mengalami ketidaknyamanan dan kepenatan yang harus dihadapi dalam menjalankan aktivitasnya seharihari akibat buruknya kualitas pelayanan terhadap transportasi publik. Begitupun dengan permasalahan yang sering dihadapi oleh para pengguna KRL diantaranya adalah seringnya terjadi gangguan, kereta anjlok, dan masih banyak lagi permasalahan-permasalahan yang dirasakan pengguna KRL. Atas dasar permasalahan itulah pemerintah akhirnya membuat alternatif transportasi umum lain yaitu MRT yang diresmikan pada 24 Maret 2019, lalu. Menurut gubernur DKI Jakarta Anies Baswedan, pembangunan MRT fase 1 telah tuntas. Ada 13 stasiun dab 8 rangkaian MRT yang akan beroperasi mulai pukul 05.30 - 22.30 WIB hingga 1 April 2019 mendatang. Sedangkan setelah 1 April 2019, rangkaian akan ditambah menjadi 16 serta jam operasionalnya dimulai sejak pukul 05.00-00.00 WIB. Anies juga menuturkan bahwa sudah ada 71 masinis dan 350 tenaga kerja operasional. Perkiraan penumpang awal sebanyak 65.000 perhari dan akan ditingkatkan menjadi 130.000 perhari. Menurutnya, moda transportasi tersebut bagian dari Jak Lingko yang diistilahkan kendaraannya Ratangga. Pada saat ini MRT telah terintegrasi dengan Transjakarta dan kedepan akan tersambung dengan stasiun kereta listrik (www.google.com)

Masry (2002) menyatakan bahwa variabel bukti fisik, daya tanggap, kehandalan dan jaminan memiliki pengaruh positif dan signifikan terhadap kepuasan pelanggan, sementara variabel empati tidak memiliki pengaruh signifikan terhadap kepuasan pelanggan. Sementara 
menurut Manurung (2018) menyatakan bahwa dimensi bukti fisik, kehandalan, daya tanggap, jaminan dan empati memiliki pengaruh yang positif dan signikan terhadap kepuasan pelanggan.

Berdasarkan uraian latar belakang tujuan penelitian ini adalah untuk menguji pengaruh kualitas pelayanan terhadap kepuasan konsumen pada bisnis jasa transportasi MRT Jakarta.

\section{KAJIAN LITERATUR \\ Kualitas Pelayanan}

Kualitas merupakan sebuah kata yang bagi perusahaan penyedia jasa menjadi sesuatu yang harus dikerjakan dengan baik. Nilai yang diberikan pelanggan, sangat kuat didasari oleh faktor kualitas jasa. Dimana kualitas suatu produk/jasa memenuhi spesifikasi-spesifikasinya. Kualitas pelayanan berpusat pada upaya pemenuhan kebutuhan dan keinginan pelanggan serta ketetapan penyampaiannya untuk mengimbangi harapan pelanggan.Menurut Lewis \& Booms dalam Tjiptono (2012:157), Kualitas pelayanan secara sederhana, yaitu ukuran seberapa bagus tingkat layanan yang diberikan mampu sesuai dengan ekspektasi pelanggan. Mengutip dari pendapat Zeithaml, Berry dan Parasuraman Menurut Nasution (2004:114) Kualitas pelayanan adalah tingkat keunggulan yang diharapkan dan pengendalian atas tingkat keunggulan tersebut untuk memenuhi keinginan pelanggan.

Definisi mengenai kualitas pelayanan mungkin berbeda, namun secara khusus meliputi hal dalam menentukan apakah pelayanan yang dirasakan sesuai dengan harapan pelanggan. Pelanggan menilai kualitas pelayanan berdasarkan persepsi mereka dari hasil teknis yang diberikan yang merupakan proses dimana hasil disampaikan (dalam Lupiyoadi dan A. Hamdani, 2011) bahwa keberhasilan suatu perusahaan dalam memberikan layanan yang bermutu kepada pelanggannya, pencapaian pangsa pasar yang tinggi, serta peningkatan profit perusahaan sangat ditentukan oleh pendekatan yang digunakan.

\section{Kepuasan Pelanggan}

Kepuasan adalah ketika konsumen memenuhi kebutuhannya, hal itu merupakan konsumen memberikan penilaian terhadap sebuah fitur produk atau jasa, atau produk atau jasa itu sendiri. Hal itu merupakan suatu kepuasan yang didapatkan kosumen yang berhubungan dengan pemenuhan kebutuhan. Menurut Kotler \& Kell er (2012:150) Kepuasan adalah perasaan puas atau kecewa seseorang yang dihasilkan dari perbandingan performa produk atau hasil dengan ekspektasi. Jika performanya kurang dari ekspektasi maka pelanggan akan kecewa dan jika sesuai dengan ekspektasi konsumen akan merasa puas. Menurut Fandy Tjiptono (2014:353) , kepuasan berasal dari bahasa Latin "Satis" yang berarti cukup baik, memadai dan "Facio" yang berarti melakukan atau membuat. Secara sederhana kepuasan bisa diartikan sebagai upaya pemenuhan sesuatu atau membuat sesuatu memadai.

\section{METODE PENELITIAN}

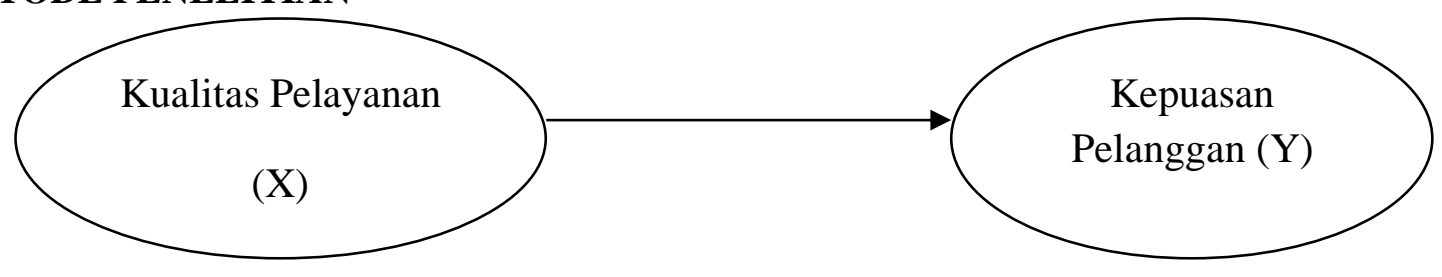

Gambar 1. Kerangka Penelitian

Sumber : Data diolah peneliti (2019) 
Menurut Wati (2018) hipotesis merupakan jawaban sementara terhadap rumusan masalah penelitian. Hipotesis dapat benar atau terbukti dan terbukti setelah didukung oleh fakta-fakta di lapangan.

Penelitian ini dilakukan dibeberapa stasiun MRT di Jakarta seperti stasiun MRT Dukuh Atas, Stasiun Bendungan Hilir, Stasiun Hotel Indonesia, dan Stasiun Lebak Bulus pada bulan Juni 2019.

Dalam penelitian ini dapat dibentuk persamaan :

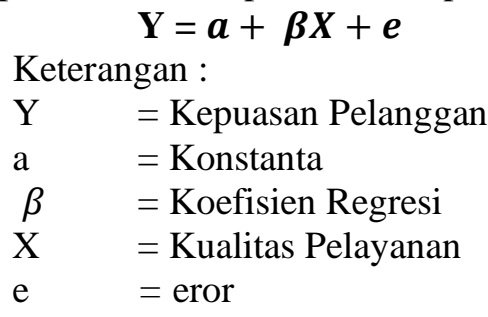

\section{HASIL DAN PEMBAHASAN}

\section{Karakteristik Responden}

Pengambilan data dilaksanakan pada 15 s.d 31 Juli 2019. Penyebaran kuesioner dilakukan dengan cara membagikan pertanyaan kuesioner kepada pengguna MRT melalui wawancara. Data yang didapat oleh peneliti ialah sebanyak 100 responden.

Tingkat persebaran responden berdasarkan jenis kelamin, data menunjukkan bahwa responden laki-laki berjumlah 39 orang atau setara dengan 39\%. Sementara responden perempuan berjumlah 61 orang atau setara dengan $61 \%$. Yang artinya mayoritas responden pengguna jasa transportasi MRT perempuan lebih banyak dibandingkan dengan pengguna MRT laki-laki. Tingkat persebaran responden berdasarkan usia, data menunjukkan bahwa responden kategori usia pengguna MRT berusia $<25$ tahun berjumlah 30 orang atau 30\%, pengguna MRT berusia 25-40 tahun berjumlah sebanyak 40 orang atau $40 \%$, dan responden berusia $>40$ tahun berjumlah 30 orang atau 30\%. Tingkat persebaran berdasarkan pendidikan terakhir, data menunjukkan bahwa responden dengan pendidikan terakhir SD hanya terdapat 1 orang atau $1 \%$, pendidikan terakhir SMP sebanyak 5 orang atau 5\%, pendidikan terkhir SMA/K terdapat 55 orang atau 55\%, pendidikan terakhir Diploma terdapat 6 orang atau 6\%, pendidikan terakhir Sarjana atau S1 terdapat 33 orang atau $33 \%$, dan untuk pendidikan terakhir terakhir Pascasarjana tidak da. Hal ini menunjukkan bahwa mayoritas pengguna transportasi umum MRT berpendidikan SMA/K.

\section{Analisa Data}

\section{Uji Instrumen Penelitian}

Dengan jumlah 100 responden, jika nilai uji > 0,361 dinyatakan valid. Dari hasil pengolahan data kuisioner pada 100 responden, diperoleh hasil data sebagai berikut:

Uji validitas kualitas pelayanan syarat minimum untuk dianggap valid apabila $r>0,3$, jadi bila koefisien korelasi kurang dari 0,3 maka butir instrumen tersebut dinyatakan tidak valid. Pengujian validitas variabel Reability, semua indikator pertanyaan valid karena memiliki nilai korelasi di atas 0,3. Terdapat beberapa indikator yang nilainya dibawah 0,361. Berdasarkan 
output SPPS uji reliabilitas dengan menggunakan teknik alpa croncbach, nilainya adalah 0,906 artinya lebih lebih besar dari 0,7. Sehingga instrumen penelitian variabel $\mathrm{X}$ diatas dianggap reliable.

Uji validitas kepuasan pelanggan syarat minimum untuk dianggap valid apabila $r>0,361$, jadi bila koefisien korelasi kurang dari 0,361 maka butir instrumen tersebut dinyatakan tidak valid. Pengujian validitas variabel kepuasan Pelanggan, semua indikator pertanyaan valid karena memiliki nilai korelasi di atas 0,361. Berdasarkan output SPPS uji reliabilitas dengan menggunakan teknik alpa croncbach, nilainya adalah 0,765 artinya lebih lebih besar dari 0,7. Sehingga instrumen penelitian variabel Y diatas dianggap reliable.

\section{Uji Asumsi Klasik}

Hasil uji asumsi klasik menunjukan bahwa uji normalitas terpenuhi, dengan menggunakan uji statistik non-parametrik Kolmogorov-Smirnov (K-S) yang mana kriteria suatu data residual berdistribusi normal yaitu nilai Asymp. Sig. (2-tailed) > 0,05 dan hasil menunjukan bahwa data dalam penelitian ini berdistribusi normal karena nilai nya KolmogorovSmirnov > 0.05 yaitu 0.200. kemudian untuk uji multikolinieritas hasil nya menunjukan bahwa antara variabel kualitas pelayanan dan kepuasan pelanggan tidak berkorelasi atau multikolinieritas tidak terjadi dalam model penelitian karena diperoleh nilai VIF lebih kecil dari 10 yaitu 1.000 untuk variabel kualitas pelayanan dan kepuasan pelanggan. Hasil uji heteroskedastisitas menunjukan bahwa tidak terjadi heteroskedastisitas karena terlihat pada titik-titik yang menyebar secara acak diatas dan dibawah angka nol (0) dan tidak membentuk suatu pola tertentu, maka dapat dikatakan bahwa regresi tidak mengalami gangguan heteroskedastisitas sehingga model regresi layak dipakai.

\section{Gambar 2}

Scatterplot Uji Heteroskedastisitas

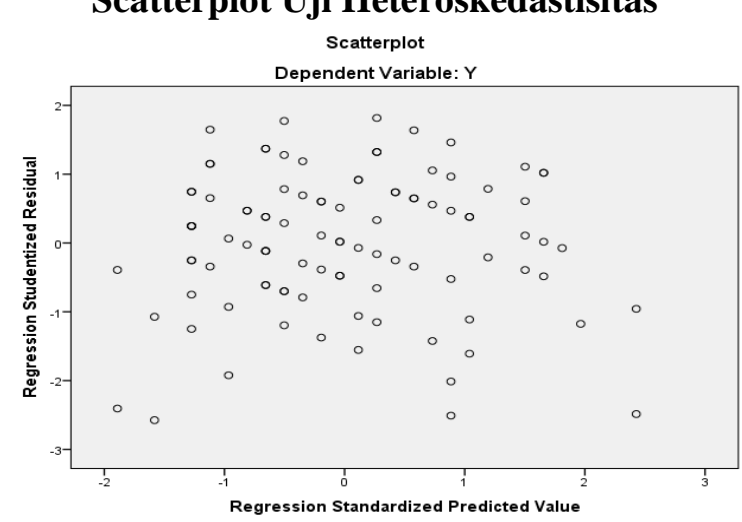

Sumber : Data diolah peneliti

\section{Analisis Regresi}

\section{Uji Keberartian Model (Uji F)}

Uji F dilakukan untuk melihat apakah koefisien regresi berganda yang didapat dalam model bisa digunakan untuk memprediksi nilai variabel tak bebas yaitu Y. Hal ini dilakukan apakah variabel bebas secara bersama-sama berpengaruh secara signifikan terhadap (Y). 
Tabel 1. Hasil Uji Keberartian Model (Uji F)

ANOVA ${ }^{\mathrm{a}}$

\begin{tabular}{|ll|l|l|l|l|l|}
\hline \multicolumn{2}{|l|}{ Model } & $\begin{array}{l}\text { Sum } \\
\text { Squares }\end{array}$ & Df & Mean Square & F & Sig. \\
\hline 1 & Regression & 5,581 & 1 & 5,581 & 33,887 &, $000^{\mathrm{b}}$ \\
& $\begin{array}{l}\text { Residual } \\
\end{array}$ & 16,139 & 98 &, 165 & & \\
\hline & Total & 21,720 & 99 & & & \\
\hline
\end{tabular}

a. Dependent Variable: Y

b. Predictors: (Constant), $\mathrm{X}$

Berdasarkan Tabel diatas, diketahui bahwa nilai $\mathrm{F}$ hitung sebesar 33,887 dengan nilai Sig. sebesar $0,000<0,05$. Jadi dapat disimpulkan bahwa variabel Kualitas Pelayanan secara simultan mampu menjelaskan perubahan pada variabel terikat (Kepuasan Pelanggan) dinyatakan model regresi fit dan layak digunakan sehingga dapat dilanjutkan untuk pengujian.

\section{Uji Signifikansi Koefisien (Uji t)}

Uji t dimaksudkan untuk membuktikan kebenaran hipotesis penelitian bahwa ada pengaruh secara parsial anatara variabel independen (Kualitas Pelayanan) terhadap variabel dependen (Kepuasan Pelanggan).

Persamaan Regresi Estimasi yang digunakan adalah :

$Y=\alpha+\beta 0,356+0,0,913 \mathrm{X}$

Tabel 2. Hasil Uji Signifikan Koefisien (Uji t)

\section{Coefficients $^{\mathrm{a}}$}

\begin{tabular}{|c|c|c|c|c|c|c|}
\hline \multirow{2}{*}{\multicolumn{2}{|c|}{ Model }} & \multicolumn{2}{|c|}{ Unstandardized Coefficients } & \multirow{2}{*}{$\begin{array}{l}\text { Standardized } \\
\text { Coefficients } \\
\text { Beta }\end{array}$} & \multirow[b]{2}{*}{$\mathrm{T}$} & \multirow[t]{2}{*}{ Sig. } \\
\hline & & B & Std. Error & & & \\
\hline \multirow[t]{2}{*}{1} & (Constant) & 1,843 & 3,323 & &, 554 & ,581 \\
\hline & $X$ & ,182 & ,032 & ,504 & 5,778 & ,000 \\
\hline
\end{tabular}

a. Dependent Variable: Y

Berdasarkan Tabel diatas, nilai Sig untuk Kualitas Pelayanan sebesar 0,000 $<0,05$. Hal ini berarti Kualitas Pelayanan memiliki pengaruh positif terhadap Kepuasan Pelanggan, maka semakin baik Kualitas Pelayanan, Kepuasan Pelanggan juga semakin tinggi. 
Tabel 3.Tabel Uji t

\section{Coefficients $^{\mathbf{a}}$}

\begin{tabular}{|c|c|c|c|c|c|c|c|c|}
\hline \multirow[b]{2}{*}{ Model } & \multicolumn{2}{|c|}{$\begin{array}{l}\text { Unstandardized } \\
\text { Coefficients }\end{array}$} & \multirow{2}{*}{\begin{tabular}{|l}
$\begin{array}{l}\text { Standardized } \\
\text { Coefficients }\end{array}$ \\
Beta
\end{tabular}} & \multirow[b]{2}{*}{$\mathrm{t}$} & \multirow[b]{2}{*}{ Sig. } & \multicolumn{3}{|c|}{ Correlations } \\
\hline & B & $\begin{array}{l}\text { Std. } \\
\text { Error }\end{array}$ & & & & $\begin{array}{l}\text { Zero- } \\
\text { order }\end{array}$ & Partial & Part \\
\hline 1 (Constant) & ,356 & ,662 & &, 537 & ,592 & & & \\
\hline $\bar{X}$ & ,913 & ,157 & ,507 & 5,821 & ,000 & ,507 & ,507 & ,507 \\
\hline
\end{tabular}

a. Dependent Variable: Y

*) Uji t dengan SPSS

\section{Koefisien Determinasi}

Tabel 4. Hasil Uji Koefisien Determinasi

\section{Model Summary}

\begin{tabular}{|c|c|c|c|c|c|c|c|c|c|}
\hline \multirow[b]{2}{*}{ Model } & \multirow[b]{2}{*}{$\mathrm{R}$} & \multirow[b]{2}{*}{$\begin{array}{l}\mathrm{R} \\
\text { Square }\end{array}$} & \multirow[b]{2}{*}{$\begin{array}{l}\text { Adjusted } \\
\text { R Square }\end{array}$} & \multirow{2}{*}{$\begin{array}{l}\text { Std. } \\
\text { Error of } \\
\text { the } \\
\text { Estimate }\end{array}$} & \multicolumn{5}{|c|}{ Change Statistics } \\
\hline & & & & & $\begin{array}{l}\mathrm{R} \\
\text { Square } \\
\text { Change }\end{array}$ & $\begin{array}{l}\mathrm{F} \\
\text { Chang } \\
\mathrm{e}\end{array}$ & df1 & df 2 & $\begin{array}{l}\text { Sig. F } \\
\text { Change }\end{array}$ \\
\hline 1 &, $507^{\mathrm{a}}$ & 257 & 249 & 4058 & 257 & 33,887 & 1 & 98 & ,000 \\
\hline
\end{tabular}

a. Predictors: (Constant), $\mathrm{X}$

Nilai Adjusted R Square menjelaskan besaran persen variabel dependen (Kepuasan Pelanggan) diterangkan oleh variabel independen (Kualitas Pelayanan), dengan nilai sebesar 0,249 atau 24,9\% yang berarti variasi nilai Kepuasan Pelanggan tercerminkan oleh variasi nilai Kualitas Pelayanan sebesar $24,9 \%$, sisanya yaitu $75,1 \%$ dipengaruhi oleh variabel lain yang tidak diteliti.

\section{PEMBAHASAN}

Hasil penelitian menunjukkan bahwa ada pengaruh tangible, reliability, responsiveness, assurance dan, emphaty terhadap kepuasan konsumen pada bisnis jasa transportasi MRT Jakarta. Hal ini dibuktikan dengan hasil statistic thitung sebesar 0,913 dengan signifikansi sebesar 0,000 . Oleh karena nilai signifikansi lebih kecil dari $0,05(0,000<0,05)$, maka penelitian ini berhasil membuktikan hipotesis yang menyatakan bahwa "terdapat pengaruh signifikan kualitas pelayanan (tangible, reliability, responsiveness, assurance dan,emphaty) terhadap kepuasan konsumen". Hasil uji determinan R2 pada penelitian ini diperoleh nilai determinan $\mathrm{R}^{2}$ sebesar 0,249 atau 24,9\% yang berarti variasi nilai Kepuasan Pelanggan tercerminkan oleh variasi nilai Kualitas Pelayanan sebesar 24,9\%, sisanya yaitu 75,1\% dipengaruhi oleh variabel 
lain yang tidak diteliti. Hal ini sejalan dengan penelitian Manurung (2018) yang menjelaskan bahwa dimensi bukti fisik, kehandalan, daya tanggap, jaminan dan empati memiliki pengaruh yang positif dan signikan terhadap kepuasan pelanggan.

\section{PENUTUP}

\section{Kesimpulan}

Penelitian ini bertujuan untuk mengetahui pengaruh kualitas pelayanan seperti tangible, reliability, responsiveness, assurance dan emphaty terhadap kepuasan konsumen pada bisnis jasa transportasi MRT. Maka dalam penelitian ini diperoleh dengan menyebarkan angket kepada responden serta melakukan wawancara untuk mengetahui hasilnya. Peneliti melakukan pengujian analisis data dengan menggunakan program SPSS. Berdasarkan uraian diatas hasil yang didapat dari pengolahan data menggunakan program SPSS, dapat disimpulkan bahwa Kualitas Pelayanan memiliki pengaruh Terhadap Kepuasan Pelanggan MRT Jakarta.

Berdasarkan hasil penelitian, PT.MRT Jakarta diharapkan bisa mempertahankan kualitas yang ada saat ini. PT.MRT Jakarta sebaiknya memperhatikan mengenai kelengkapan fasilitas penunjang seperti tempat duduk, mesin ATM, dan lain lain. Hal ini dikarenakan masih terdapat beberapa stasiun MRT yang masih belum terdapat fasilitas penunjang yang disebutkan diatas. Petugas MRT juga diharapkan lebih baik lagi dalam melayani. Hal ini dikarena dibeberapa stasiun petugas melayani masih kurang dalam hal keramah tamahan. Tempat duduk didalam MRT juga diharapkan bisa dibuat lebih nyaman sehingga penumpang bisa duduk dengan nyaman. Stasiun MRT juga perlu menyiapkan ramp portable untuk pelanggan MRT yang menggunakan kursi roda.

\section{REFERENSI}

Kotler, P, Keller, K, L. 2012. Marketing Manajemen, $14^{\text {th }}$ Edition. New Jersey: Practice Hall inc Lupiyoadi, Rambat dan Hamdani, A, 2011. Manajemen Pemasaran Jasa. Edisi Kedua, Salemba Empat, Jakarta

Manurung, Bob M.T dkk. (2018) Pengaruh Kualitas Pelayanan Jasa Kereta Rel Listrik (KRL) Commuter Line Terhadap Kepuasan Pelanggan Dalam Upaya Peningkatan Ketahanan Wilayah. Tesis, Magister Ketahanan Nasional Universitas Gadjah Mada

Masri, Henry (2002) Analisis Pengaruh Faktor-Faktor Kualitas Pelayanan Terhadap Kepuasan Pelanggan Jasa Transportasi Kereta Api (Studi Kasus Pada PT Kereta Api Indonesia DAOP IV Semarang). Masters Thesis, Program Pascasarjana Universitas Diponegoro

Tjiptono, Fandy. 2012. Sevice Management Mewujudkan Layanan Prima. Yogyakarta: CV Andi Offset

Tjiptono, Fandy. 2014. Pemasaran Jasa. Yogyakarta: CV. Andi Offset

Sugiyono. 2011. Metode Penelitian Kuantitatif Kualitatif dan R\&D. Bandung: Alfabeta

Wati, L.N. (2018). Metodologi Penelitian Terapan, Aplikasi SPSS, EVIEWS, Smart PLS, dan AMOS. Edisi 2. Percetakan Pustaka AMRI: Jakarta

Zeithaml, et al: Service Quality Through Web sites: a Critical Review of Extant Knowledge Journal of the Academy of Marketing Science 